Bangl. J. Vet. Med. (2007). 5 (1 \& 2): 19-23

\title{
COMPARATIVE EFFICACY OF AVINEW (VG/GA STRAIN) AND BCRDV (F STRAIN) VACCINES AGAINST NEWCASTLE DISEASE IN BROILER CHICKENS
}

\author{
M. S. Mahmud ${ }^{1}$, M. T. Hossain, P. Monoura ${ }^{2}$ and M. M. Amin ${ }^{*}$ \\ Department of Microbiology and Hygiene, Faculty of Veterinary Science, Bangladesh Agricultural University, \\ Mymensingh-2202, Bangladesh \\ *Corresponding author's e-mail address: maminbau@gmail.com
}

\begin{abstract}
A study was conducted for the detection of persistence of maternal antibody as well as the comparative efficacy of Avinew (VG/GA Strain) and BCRDV (F Strain) vaccines against Newcastle disease during the period from January to April 2006 using 100 day-old broiler chicks divided into three groups namely A, B and C. Birds of groups A and B consisting each of 40 were primarily vaccinated intraocularly (IO) with Avinew and BCRDV respectively at the age of day three (3) and secondarily with the same vaccines, as the cases were, on day 20. Sera samples were obtained from 10 randomly selected birds on each occasion of day 1,10,17, 27, 30, 34 and 44 of age of birds. Birds of group $\mathrm{C}$ were maintained as unvaccinated control for the determination of existence of maternal antibody parallel to the day of vaccination and challenge. It was observed that following primary vaccination in case of group A, the HI titres with a mean \pm SD on day 10 and 17 were 121.6 \pm 19.2 and $60.8 \pm 9.60$ respectively as against at mean titres \pm SD of $57.6 \pm 12.8$ and $30.4 \pm 4.80$ in case group B respectively. On the other hand, subsequent to secondary vaccination, sera samples obtained from group A on day 27 had a mean \pm SD of $\mathrm{HI}$ titres $128 \pm 0$ and in case of group B, the performance of Avinew in respect of such titre was $57.6 \pm 12.8$ on day 27. Thus it was indicated that performance of Aninew in respect of elucidation of $\mathrm{HI}$ antibody was comparatively better than that of BCRDV. In case of unvaccinated control birds of group $C$, the mean of existence of maternal antibody with \pm SD were $512 \pm$ $0,54.4 \pm 14.66,24 \pm 8,12.8 \pm 8.54, \leq 4, \leq 4$ and $\leq 4$ at the age of day $1,10,17,27,30,34$ and 44 respectively. One half of vaccinated birds of groups $A$ and $B$ were subjected to challenge test with a virulent isolate of NDV on each of two occasion of day 30 and 44 of age of birds where it was observed that $100 \%$ of both the groups of A and B were refractory to each test whereas $95 \%$ and $85 \%$ of the remaining half of birds of groups A and B resisted the challenge exposure. It was found that maternal antibody against NDV in chicks persisted to a minimal until the age of day 27 and none at day 30 or 34 . The analysis of HI titres by Student's t-test revealed that Avinew vaccinated group maintained significantly higher HI titres following primary and secondary vaccination as well as during first challenge than that of BCRDV vaccinated group.
\end{abstract}

Key wards: Avinew, BCRDV, efficacy, vaccine, broiler chicks

\section{INTRODUCTION}

In the recent years, poultry raising has become a growing and prospective industry in Bangladesh. Despite special emphasis of the state on this sector, the development of poultry industry is seriously threatened by the outbreaks of acute, contagious and fatal diseases. Newcastle disease (ND) also known as Ranikhet disease stands as a major problem towards the development of poultry industry in Bangladesh. It is caused by Avulovirus, a newly formed genus under paramyxoviridae (De Leeuw and Peeters, 1999; Chang et al., 2001; Mayo, 2002) which is a single stranded RNA virus. The factors that affect the disease may be host, species, age, immune status, infection with other organisms and environmental stress (Cheville et al., 1972; Lancaster, 1981; Campbell, 1986).The disease is characterized by sudden appearance and rapid spread within the flock with high morbidity and mortality. It may cause $100 \%$ mortality in young chickens and $80-90 \%$ in adult chickens (Brandly, 1950; Chowdhury et al., 1982).

Present address: ${ }^{1}$ Department of Microbiology, Gono Bishwabidyalay, Savar, Dhaka, ${ }^{2}$ Animal Health Research Division, BLRI, Savar, Dhaka. 
Newcastle disease is endemic in Bangladesh with prevalence of viscerotropic velogenic strains (Chowdhury et al., 1982; Islam, 2003). The pathogenicity of velogenic NDV largely depends on F- protein cleavage site (Lin et al., 2003). Proper biosecurity measures in farm and effective vaccination of flock are the only means to control this disease. Vaccination schedule against ND as followed by the Department of Livestock Services (DLS) includes administration of live lentogenic vaccine termed as Baby Chick Ranikhet Disease Vaccine (BCRDV) of F-strain by intraocular inoculation at the first week and $3^{\text {rd }}$ week old chicks followed by a live mesogenic vaccine termed as Ranikhet Disease Vaccine (RDV) of M-strain by intramuscular route at day 10-12 weeks of age and are repeated at every six months interval. In spite of such a well circulated schedule, these are not being followed in some instances. Thus, the disease is found to appear in every year in the form of epidemic in some areas which causes $40-60 \%$ of the total mortality rate of poultry population in Bangladesh (Chowdhury et al., 1982; Talha et al., 2001). However, the schedule of vaccination also differs with type of flock such as broiler and layer, but should be followed strictly as the cases are. Newcastle disease vaccines produced in Bangladesh are not sufficient to meet the demand of growing poultry industry. As a result, quite a handsome quantity of live vaccines belonging to Lentogenic and Mesogenic strains, cloned, live and inactivated vaccines are imported. There are varieties of modes and means of transport of vaccines and also variation in maintenance of cold-chain system at all stages of district, thana, union, village and farm level in Bangladesh. This is one of the important reasons of vaccination failure, although there may be other, which causes economic losses to the farmers. In most of the cases, these vaccines are found effective against ND although there is very little study on the comparative efficacy of these vaccines, particularly with those produced by the DLS and other local manufacturers. It is also unfortunate that there is no prerequisite or compulsion for such reports of the NDvaccines imported specially in regard to the influence of varied climatic environment that Bangladesh have and such other stresses where chickens are put to while being reared. In consideration of these factors, this study was undertaken to observe the persistence of maternally derived antibody to NDV in chicks and also to compare the efficacy of Avinew (VG/GA strain, Lentogenic) and BCRDV (F strain, Lentogenic) in broiler chickens.

\section{MATERIALS AND METHODS}

The whole experiment was conducted during the period from January to April 2006 in the Department of Microbiology and Hygiene, Faculty of Veterinary Science, Bangladesh Agricultural University, Mymensingh.

\section{Experimental chickens}

A total of 200 day-old-chicks of Cobb-500 strain of broiler with courtesy of Advanced Animals Science Co. Ltd. with the history of vaccination of parent stock against Newcastle disease (ND) were collected from the Peoples Hatchery Ltd., Tangail. The birds were supplied with feed (Quality Feed Co. Ltd.) and water ad libitum maintaining strict biosecurity.

\section{Newcastle disease vaccines}

Lyophilized NDV vaccines 'Avinew' and 'BCRDV' were used during the experiment. The Avinew (VG/GA strain, Lentogenic) was collected with the courtesy of Advance Animal Science Co. Ltd., Lalmatia, Dhaka and Baby Chick Ranikhet Disease Vaccine (BCRDV, Lentogenic) was collected from Sadar Veterinary Hospital, Mymensingh. The vaccines were stored and diluted during use according to the instruction of the manufacturers.

\section{Virulent Newcastle disease virus (NDV) isolate}

The virulent NDV isolate obtained from the laboratory repository of the Department of Microbiology and Hygiene, BAU, Mymensingh was propagated to activate the virus into 10-day-old embryonated chicken eggs through allantoic cavity route. After four serial passages in embryo, the allantoic fluid was collected and stored at $-20{ }^{0} \mathrm{C}$ until used.

\section{Vaccination schedule followed}

A total of 100 chickens were divided into three groups as A, B and C where groups A and B contained 40 birds each and group $\mathrm{C}$ contained 20 birds. Each vial of Avinew vaccine was diluted with $30 \mathrm{ml}$ of diluent as was supplied with it and BCRDV was diluted with $3 \mathrm{ml}$ of distilled water at the time of vaccination. 
The experimental chickens of groups A and B were primarily vaccinated via intraocular route (IO) with Avinew (VG/GA strain, Lentogenic) and BCRDV (F strain, Lentogenic) respectively at day 3 of age of chicks and at day 20 of age chicks were provided with a secondary dose through IO route with the same vaccine. Chickens of group $\mathrm{C}$ were kept as control. Blood was collected from 10 randomly selected chickens from each group at the age of day 1, 10, 17, 27, 30, 34 and 44 for the determination of HI antibody titre in each serum.

\section{Haemagglutination inhibition (HI) test}

The procedure of HI test was followed as per method described by Anon. (1971) and divided into two parts:

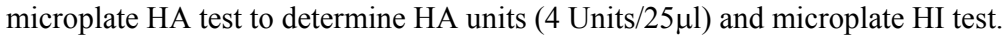

\section{Challenge test}

Half of the vaccinated and control chicks were challenged with a virulent field isolate of NDV after 10 days (30 days age of birds) and rest half after 24 days (44 days age of birds) of second vaccination. Each bird was inoculated via intramuscular route with $0.5 \mathrm{ml}$ of $100 \mathrm{ELD}_{50}$ viruses and was kept isolate for observation of any clinical signs or death. The pattern of death was recorded.

\section{Statistical analysis}

Data obtained were statistically for differences in the HI titres using Student's ' $t$ '-test according to the standard procedures as described by Snedecor and Cochran (1980).

\section{RESULTS AND DISCUSSION}

Persistence of maternally (passive) derived antibody (MDA) was measured on a number of occasions starting from day 1 to day 44 and the titres are presented in Table 1. It was observed that such antibody continued to exist to a minimal until the age of day 27 and none at the age of day 30 or 34 . In this regard, it may be recalled that the broiler chicks are generally hatched from parents with a high degree of antibody. The findings of this investigation in respect of persistence for quite an appreciable period of day 27 of age of chicks is in agreement with Balla (1986) and Saeed et al. (1988) who reported that MDA declined to zero after the age of 25 days of chicks. However, there are other reports of retention of MDA such as those of Chowdhury et al. (1982) and Islam et al. (2003) where the period of its existence were stated to be 12 and 15 days age of chicks respectively.

Table 1. HI of titre (Mean $\pm \mathrm{SD}$ ) of groups A and B prior and following primary and secondary vaccination and before challenge compared to unvaccinated group $\mathrm{C}$

\begin{tabular}{|c|c|c|c|c|c|c|c|c|}
\hline \multirow[t]{3}{*}{ Groups } & \multirow[t]{3}{*}{ Vaccine } & \multicolumn{7}{|c|}{ HI titres $(n=10)$} \\
\hline & & \multirow{2}{*}{$\begin{array}{l}\text { Pre-primary } \\
\text { Day } 1\end{array}$} & \multicolumn{2}{|l|}{ Post-primary } & \multicolumn{4}{|c|}{ Post-secondary } \\
\hline & & & Day 10 & Day 17 & Day 27 & Day 30 & Day 34 & Day 44 \\
\hline A & $\begin{array}{l}\text { Avinew } \\
\text { (VG/GA } \\
\text { strain) }\end{array}$ & $512 \pm 0.00$ & $121.6 \pm 19.2 * *$ & $60.8 \pm 9.60 * *$ & $128 \pm 0.00 * *$ & $57.6 \pm 12.8^{* *}$ & $30.4 \pm 4.80$ & $20 \pm 8.2$ \\
\hline B & $\begin{array}{l}\text { BCRDV } \\
\text { (F strain) }\end{array}$ & $512 \pm 0.00$ & $57.6 \pm 12.8$ & $30.4 \pm 4.80$ & $57.6 \pm 12.8$ & $22.4 \pm 9.99$ & $18.6 \pm 8.2$ & $14 \pm 6.4$ \\
\hline $\mathrm{C}$ & Control & $512 \pm 0.00$ & $54.4 \pm 14.66$ & $24 \pm 8.00$ & $12.8 \pm 8.54$ & $\leq 4 \pm 0$ & $\leq 4 \pm 0$ & $\leq 4 \pm 0$ \\
\hline
\end{tabular}

$\mathrm{n}=$ Number of sera samples, ${ }^{* * \text { Significant at } \mathrm{p}<0.01 .}$

One of the principal objectives of this study was to observe the comparative performance of Avinew (Advanced Science Co. Ltd.) and BCRDV (DLS) in chicks. The mean \pm SD of HI titres of 10 birds in each case and occasion from groups A, B and C measured at stages of pre-primary (day 1), post-primary (day 10 and 17) and post-secondary (day 27, 30, 34 and 44) vaccination are mentioned in Table 1. 
It was observed that the mean $\pm \mathrm{SD}$ of sera samples of groups A and B were $121.6 \pm 19.2$ and $57.6 \pm 12.8$ respectively on day 10 whereas such a mean titres were $60.8 \pm 9.6$ and $30.4 \pm 4.8$ on day 17 respectively. Similarly it was found that on day 27, the mean \pm SD of HI titres of group A was $128 \pm 0$ and group B was 57.6 \pm 12.8 . On the following occasion of day 30,34 and 44 the mean \pm SD of $\mathrm{HI}$ in group A were $57.6 \pm 12.8,30.4$ \pm 4.8 and $20 \pm 8.19$ respectively and in group B were $22.4 \pm 9.99,18.6 \pm 8.2$ and $14 \pm 6.4$ respectively. A comparison of those would indicate the superiority of Avinew (VG/GA strain) to BCRDV although when the birds were subjected to protection test the picture was not as clearly evident as the mean HI titres were. In case of group $\mathrm{C}$, the decline of maternal antibody appeared to be gradual with increase of age of birds.

Protection tests of two sets of vaccination of birds of group A as well as B and unvaccinated control (group C) birds were conducted at day 30 and 44 (10 and 24 days postsecondary vaccination respectively). It was observed that $100 \%$ of both the groups of first set of birds were refractory to such challenge infection (Table 2).

Table 2. Results of challenge test to ND following vaccination

\begin{tabular}{|c|c|c|c|c|c|c|c|c|c|}
\hline \multirow[t]{2}{*}{ Groups } & \multirow[t]{2}{*}{$\begin{array}{l}\text { Vaccines } \\
\text { used }\end{array}$} & \multicolumn{4}{|c|}{$\begin{array}{l}\text { Challenge of first half of birds } \\
\text { (Day 30) }\end{array}$} & \multicolumn{4}{|c|}{$\begin{array}{l}\text { Challenge of second (remaining) half of } \\
\text { birds (Day 44) }\end{array}$} \\
\hline & & $\begin{array}{l}\text { No. of } \\
\text { birds }\end{array}$ & $\begin{array}{l}\text { Birds } \\
\text { alive }\end{array}$ & $\begin{array}{l}\text { Birds } \\
\text { dead }\end{array}$ & $\begin{array}{l}\% \text { of } \\
\text { protection }\end{array}$ & $\begin{array}{l}\text { No. of } \\
\text { birds }\end{array}$ & $\begin{array}{l}\text { Birds } \\
\text { alive }\end{array}$ & $\begin{array}{l}\text { Birds } \\
\text { dead }\end{array}$ & $\begin{array}{l}\% \text { of } \\
\text { protection }\end{array}$ \\
\hline A & $\begin{array}{l}\text { Avinew } \\
\text { (VG/GA } \\
\text { strain) }\end{array}$ & 40 & 40 & 0 & $100 \%$ & 40 & 38 & 2 & $95 \%$ \\
\hline B & $\begin{array}{l}\text { BCRDV } \\
\text { (F strain) }\end{array}$ & 40 & 40 & 0 & $100 \%$ & 40 & 34 & 6 & $85 \%$ \\
\hline $\mathrm{C}$ & Control & 10 & 0 & 10 & $0 \%$ & 10 & - & 10 & $0 \%$ \\
\hline
\end{tabular}

On the second instance, when the remaining birds were exposed to an isolate of field velogenic virus as was in the first instance, it was noted that $95 \%$ of group A and $85 \%$ of group B resisted the challenge. On both the occasion, birds of the control group C succumbed to infection. Schmidt and Schmidt (1955) observed that minimum HI titre to resist challenge infection was 16 or more. However, Al-Garib et al. (2003) with reference from Borland and Allan (1980) pointed out that 'Cloning' was used to obtain viruses with high immunogenicity which might be the reason for better performance of the virus 'Avinew' (VG/GA strain). The connotation needs further investigation. There were significant $(p<0.01)$ differences of HI titres of group A (Avinew vaccinated group) and group B (BCRDV vaccinated group) following primary and secondary vaccination and during first challenge also, that is, birds of group A, maintained significantly $(\mathrm{p}<0.01)$ higher HI titres up to 34 days of age following primary and secondary vaccination and also during first challenge.

\section{ACKNOWLEDGEMENT}

The authors are thankful to Advance Animal Science Co. Ltd., Lalmatia, Dhaka for financial help during the study.

\section{REFERENCES}

1. Al-Garib SO, Gielkens ALJ and Koch G (2003). Review of Newcastle disease virus with particular references to immunity and vaccination. World's Poultry Science Journal 59: 185-197.

2. Anon. (1971). Methods for examining poultry biologics and for identification and quantifying avian pathogens. Newcastle disease, U.S. National Academy of science, Wasinghton D. C.

3. Balla L (1986). Use of a standardized HI test for monitoring immunity to Newcastle disease. I. Experiments to standardize the HI test. II. Antibody responses after different immunization schedules. Magyar Allatorvosok Lapja 41: 98-109.

4. Borland LG and Allan WH (1980). Laboratory tests for comparing live lentogenic Newcastle disease vaccines. Avian Pathology 9: 45-59.

5. Brandly CA (1950). Newcastle disease. American Journal of Veterinary Medical Association 116: 139.

6. Campbell RSF (1986). The pathogenesis and pathology of avian respiratory infection. Veterinary Bulletin 56: 521-543. 
Comparative efficacy of NDV vaccines

7. Chang PC, Hsieh ML, Shien JH, Graham DA, Lee MS and Shieh HK (2001). Complete nucleotide sequence of avian paramyxovirus type 6 isolated from ducks. Journal of General Virology 82: 2157-2168.

8. Cheville NF, Stone H, Riley J and Ritchie AE (1972). Pathogenesis of virulent Newcastle disease in chickens. Journal of the American Veterinary Medical Association 161: 169-179.

9. Chowdhury SI, Chowdhury TIMFR, Sarker AJ, Amin MM and Hossain WIMA (1982). Studies on Newcastle disease in Bangladesh. A research report. 2. The role of residual maternal antibody on immune response and selection of an optimum age for primary vaccination of chicks. pp. 12-22.

10. De Leeuw O and Peeters B (1999). Complete nucleotide sequence of NDV. Evidence for the existence of a new genus within the subfamily Paramyxovirinae. Journal of General Virolog 80: 131-136.

11. Islam MR, Huque QME, Giasuddin M, Alam J and Rahman MM (2003). Assessment of Maternal derived antibody of commercial flock against Newcastle disease. Proceedings of $3^{\text {rd }}$ International Poultry Show and Seminar, Bangladesh China Friendship Conference Center, Dhaka, Bangladesh.

12. Lancaster JE (1981). Newcastle disease. In: Gibba. E.P.J. (Ed), Virus Disease of Food Animals, Vol. 1, Disease monograph, Academic press, NewYork, pp. 433-465.

13. Lin MY, Liu HJ and Ke GM (2003). Genetic and antigenic analysis of Newcastle disease viruses from recent outbreaks in Taiwan. Avian Pathology 32: 345-350.

14. Mayo MA (2002). A Summary of taxonomic changes recently approved by ICTV. Archives of Virology 147: 1655-1656.

15. Saeed Z, Ahmad S, Rizvi AR and Ajmal M (1988). Role of maternal antibody in determination of an effective Newcastle disease vaccination programme. Pakistan Journal of Veterinary Research 1: 18-21.

16. Schmidt U and Schmidt D (1955). Connection between hemagglutination inhibiting antibodies and immunity after vaccination against Newcastle disease. Archives of Experimental Veterinary Medicine 9: 505-516.

17. Snedecor GW and Cochran WG (1980). Statistical Methods. $7^{\text {th }}$ edn., English Language Book Society, London.

18. Talha AFSM, Hossain MM, Chowdhury EH, Bari ASM, Islam MR and Das PM (2001). Poultry diseases occurring in Mymensingh district of Bangladesh. The Bangladesh Veterinarian 18: 20-23. 